\title{
Upaya Mendongkrak Potensi Wilayah Dengan Pengenalan Kewirausahaan Desa Merbau dan Sialang Kayu Batu
}

\author{
Ari Andriyas Puji*, Satriardi, Zayyinul Hayati Zen, Dedi Dermawan, \\ Denny Astrie Anggraini, St. Nova Meirizha, Faradila Ananda Yul \\ Fakultas Teknik, Universitas Muhammadiyah Riau \\ email: andriyasari@umri.ac.id
}

\begin{abstract}
Bunut is one of the districts in the Pelalawan district of Riau province that has a lot of potential in it. So it needs to be processed to maximize the income of local residents, especially Merbau village and Sialang Kayu Batu village. An understanding of entrepreneurship should have been long echoed in the village in order to empower the lagging information regarding the importance of entrepreneurship and its management. This can be done by providing socialization to Merbau and Sialang Kayu Batu villagers because of the large amount of time and potential that can be utilized. This entrepreneurial knowledge is the initial capital for anyone who wants to move in a particular business field. Lack of information and management as well as steps to start a business are common obstacles in the community, especially in rural communities. In this regard the Industrial Engineering study program at the Muhammadiyah University of Riau, provides a wide way for the villagers of Merbau and Sialang Kayu Batu to gain additional knowledge in starting a business step. This was applied to community service with the Entrepreneurship Seminar "Efforts to Boost Regional Potential with the Introduction of Entrepreneurship in Merbau Village and Sialang Kayu Batu Village, Bunut District, Pelalawan Regency, Riau".
\end{abstract}

Kata Kunci: Entrepreneurship Training, UMKM, Industrial Engineering

\begin{abstract}
Abstrak
Bunut merupakan salah satu kecamatan di kabupaten Pelalawan provinsi Riau yang memiliki banyak potensi didalamnya. Sehingga perlu diolah untuk memaksimalkan pendapatan warga sekitar khususnya desa Merbau dan desa Sialang Kayu Batu. Pemahaman akan kewirausahaan seharusnya sudah lama di gaungkan di desa tersebut guna memberdayakan ketertinggalan informasi mengenai pentingnya kewirausahaan dan pengelolaanya. Hal itu dapat dilakukan dengan memberikan sosialisasi kepada warga desa Merbau dan Sialang Kayu Batu karena banyaknya waktu dan potensi yang bisa di manfaatkan. Pengetahuan kewirausahaan ini merupakan modal awal bagi siapa saja yang ingin bergerak di bidang usaha tertentu. Kurangnya informasi dan pengelolaan serta langkah-langkah memulai usaha merupakan suatu kendala yang umum ditemukan di masyarakat terutama masyarakat pedesaan. Berkaitan dengan hal ini prodi Teknik Industri Universitas Muhammadiyah Riau, memberikan jalan lebar bagi warga desa Merbau dan Sialang Kayu Batu untuk mendapatkan pengetahuan tambahan dalam memulai langkah sebuah usaha. Hal ini diaplikasikan pada pengabdian kepada masyarakat dengan Seminar Kewirusahaan "Upaya Mendongkrak Potensi Wilayah Dengan Pengenalan Kewirausahaan Desa Merbau Dan Desa Sialang Kayu Batu Kecamatan Bunut Kabupaten Pelalawan Riau”.
\end{abstract}

Kata Kunci: Pelatihan Kewirausahaan, UMKM, Teknik Industri

\section{PENDAHULUAN}

Bunut merupakan salah satu kecamatan di kabupaten Pelalawan provinsi
Riau yang memiliki banyak potensi didalamnya. Pemahaman akan kewirausahaan seharusnya sudah lama di 
gaungkan di desa tersebut. Pengetahuan kewirausahaan ini merupakan modal awal bagi siapa saja yang ingin bergerak di bidang usaha tertentu. Kurangnya informasi dan pengelolaan serta langkah-langkah memulai usaha merupakan suatu kendala yang umum ditemukan di masyarakat terutama masyarakat pedesaan padahal banyak potensi yang ada di kedua desa ini yang dapat dikembangkan dengan baik salah satunya adalah pengolahan madu yang saat ini cara penjualan dan pengememasannyanya masih tergolong konvensional. Tujuan kegiatan ini adalah diharapkan dapat memunculkan potensi potensi berpengaruh positif terutama di dunia usaha.

Dengan memberikan sosialisasi terhadap masyarakat dalam bentuk grup diskusi dan seminar. [1] menyatakan bahwa kewirausahaan dapat didefinisikan sebagai pengambilan risiko untuk menjalankan usaha sendiri dengan memanfaatkan peluang-peluang untuk menciptakan usaha baru atau dengan pendekatan yang inovatif sehingga usaha yang dikelola berkembang menjadi besar dan mandiri dalam menghadapi tantangan-tantangan persaingan. Wirausaha adalah orang atau individu yang melaksanakan proses penciptaan kesejahteraan/atau nilai tambah, melalui penoleran atau penetasan gagasan dengan memadukan sumber daya dan merealisasikan tersebut menjadi kenyataan. Dengan perkataan lain seseorang wirausaha itu adalah yang merintis gagasan menjadi realitas [2].

\section{METODE PENGABDIAN}

Metode yang digunakan dalam pengabdian ini adalah diskusi 2 arah dalam bentuk seminar kewirausahaan. Pendekatan yang diakukan secara terbuka karena sasarannya masyarakat umum, rancangan kegiatan ini berisi beberapa materi diantaranya pengenalan berwirausaha, motivasi berwirausaha, Inovasi berwirausaha, Peluang berwirausaha, inspirasi berwirausaha dan diskusi peserta. Ruang lingkup pengabdian ini adalah 2 desa di kabupaten pelalawan yaitu sialang kayu batu dan merbau kemudian objek nya adalah masyarakat umum.

Pelaksanaan kegiatan ini pada tanggal 28-30 Agustus 2019 pada jam 13.00 15.00. Masyarakat yang terlibat dalam seminar ini adalah ibu ibu rumah tangga. Kemudian narasumber sebagai pembicara dalam seminar ini adalah staff Dosen dari Universitas Muhammadiyah Riau dengan jumlah peserta seminar sebanyak 23 orang / desa. Bahan yang dibutuhan berupa materi wirausaha dan alat utama untuk melaksanakan kegiatan berupa laptop, proyektor dan pengeras suara. Tempat pelaksanaan kegiatan ini di rumah salah satu warga ibu Kurniati.

\section{HASIL DAN PEMBAHASAN}

Kegiatan pengabdian kepada masyarakat dengan pokok materi pengenalan usaha hingga perencanan bisnis untuk memulai usaha. Disini peserta diberikan teori pengenalan usaha, perencanaan untuk memulai usaha, contoh penerepan usaha hingga kerangka perencanaan usaha. Pelaksanaan pengabdian ini dilakukan dalam bentuk penyuluhan.

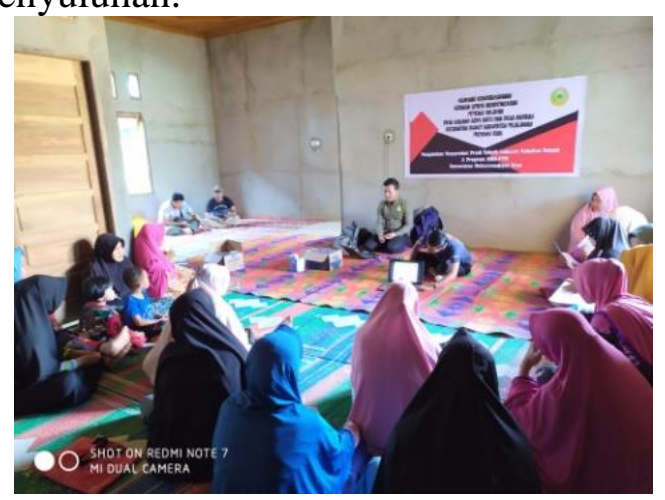

Gambar 1. Kegiatan Penyuluhan Kepada Masyarakat

Tanya jawab, diskusi hingga penyelesaian kasus. Diharapkan pelatihan ini dapat memberikan manfaat serta bekal nantinya ketika akan memulai sebuah usaha dimasyarakat. 


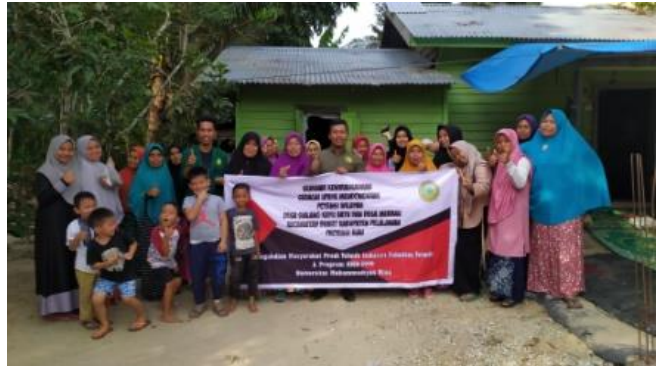

Gambar 2. Tanya Jawab dan Diskusi

Pencapaian dari pengabdian ini sampai saat ini belum ada tindak lanjut dari masyarakat yang berminat untuk memulai wirausaha, banyak pertimbangan dari masyarakat salah satunya adalah mengenai modal usaha.

\section{SIMPULAN}

Pelatihan ini memberikan beberapa materi yang terkait dengan upaya meningkatkan pengetahuan dan wawasan terhadap wirausaha, meningkatkan motivasi untuk bisa menciptakan sebuah usaha sebagai sumber untuk meningkatkan perekonomian masyarakat. Materi yang disajikan mudah diterima, dicerna, dan dipahami peserta dengan baik. Kegiatan berlangsung lancar, tepat waktu dan sesuai dengan yang diharapkan dan para peserta dapat berkomunikasi dengan para pembicara dan peserta lain dengan baik.Antusias peserta sangat baik, sehingga beberapa peserta sudah merencanakan membuka usaha nantinya.

\section{UCAPAN TERIMA KASIH}

Program pengabdian kepada Ucapan terima kasih di berikan kepada organisasi muhammadiyah, khususnya universitas muhammadiyah riau, yang telah mengakomodir kegiatan ini dengan baik. Kemudian selanjutnya ucapatan terima kasih kepada fakultas teknik khususnya prodi teknik industry. Yang telah membantu dalam pelaksanaan pengabdian dan penulisan manuskrip.

\section{DAFTAR PUSTAKA}

[1] Jong \& Wennekers. 2008. "Conceptualizing Entre-preneurial
Employee Behavior", SMEs and Entrepreneurship Programme Finance by the Netherlands Ministry of Economic Affairs.

[2] Effendy, Onong Uchjana. 2000. Ilmu Komunikasi Teori dan Praktek. Bandung : PT. Remaja Rosda Karya. 